\section{Niet vragen maar gewoon goed luisteren}

Farid komt met zijn moeder naar het intakegesprek. Ze zijn meer dan een half uur te laat. Als ik vraag waarom, kijkt Farid mij met grote ogen aan: "Ik weet het niet." Ook als zijn juf vraagt waarom hij thuis was en niet op school, heeft hij geen antwoord. Farid huilt vaak als hij thuis is en wil dan niet naar school. Maar waarom? Hij weet het niet.

Omdat de vragen geen antwoord krijgen, lijkt het me handig even geen vragen meer te stellen. Misschien ga ik het beter begrijpen als ik ga kijken op school? Achter in de klas zie ik Farid lezen met twee klasgenoten, over de processierups. Ze vinden dat een moeilijk woord, maar alledrie lezen ze vlot over die lastige beestjes die van warmte houden, in bomen leven en mensen erge jeuk bezorgen. Als ze klaar zijn, stelt de juf wat vragen. Ze wil weten waar de rupsen van houden, waar ze wonen en waarom mensen ze zo lastig vinden. De drie hebben geen idee. Nu geeft juf hen steeds een keuze. Wonen de rupsen in een boom of leven ze op de grond? Makkelijk! In een boom natuurlijk.

Achteraf vertelt ze dat alle kinderen in haar klas open vragen moeilijk vinden. Ze kunnen wel lezen en vertellen, maar een open vraag over de tekst brengt hen in de war. Het zijn allemaal pubers tussen de veertien en achttien met een intelligentie tussen de 55 en 65. Juf denkt dat open vragen hen herinneren aan al die keren dat ze geen antwoord wisten, en dus blokkeren ze als ze een vraag horen. Maar misschien is een vraag met twee antwoordmogelijkheden ook wel overzichtelijker. Wat maakt het uit, vindt de juf, als het maar werkt. "Je moet ze gewoon laten praten, dan kom je vanzelf achter wat je wil weten", zegt ze. Mijn wangen kleuren rood van schaamte. Ik heb Farid sinds het intakegesprek alleen maar open vragen gesteld. Geen wonder dat hij het

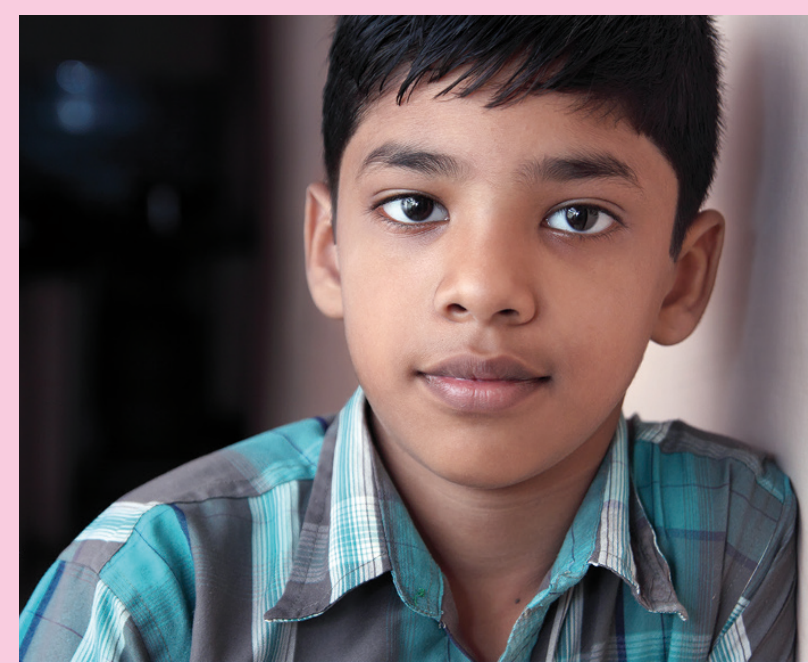

antwoord niet weet. En door al die vragen ben ik vergeten naar hem te luisteren.

Als Farid weer bij mij op kantoor komt, probeer ik te doen zoals zijn juf. Het zweet staat op mijn rug. Open vragen stellen blijkt een moeilijk af te leren psychologenkwaal. We gaan samen een mens tekenen en ik hou zo veel mogelijk mijn mond. Farid vertelt dat zijn hersens belangrijk zijn en zijn hart. Zijn hersens horen door zijn oren veel dingen, maar vaak begrijpt hij dingen niet goed. Op school zeggen ze dat hij niet goed gelooft. De jongens lachen hem uit en noemen hem een nepgelover. Dat geeft hem veel verdriet. Hij is een hindoe en doet zijn best om goed te geloven. De andere jongens zijn van de islam. Hij weet het verder ook niet. Zijn hart doet er pijn van. Hij wil graag ergens werken waar mensen ook hindoe zijn en waar hij dingen kan leren die hij begrijpt en goed kan. Hij vindt school vaak zo moeilijk. En hoe moet het verder als hij achttien is. Dan mag hij van school, maar waar moet hij dan heen?

Bijna vraag ik hem wat hij nodig heeft om een minder zwaar hart te krijgen, maar ik bijt op mijn tong. Farid zegt dat hij graag een rustige plek wil vinden en zou het fijn vinden als school en zijn ouders hem daarmee kunnen helpen. Hij vindt het fijn dat hij het verteld heeft, dat maakt zijn verdriet kleiner. Als Farid mijn kantoor verlaat ben ik een wijze les rijker: vragen stellen levert veel minder op dan iemand zijn eigen verhaal laten vertellen. 